International Journal of Academic Research in Accounting, Finance and ManagementSciences

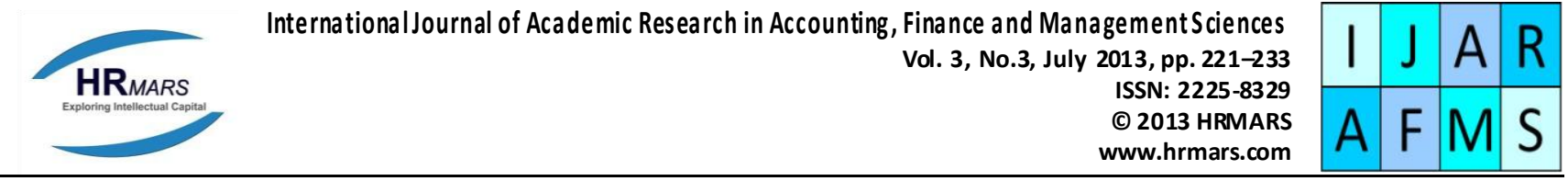

\title{
The Relationship between Product Market Competition and Capital Structure of the Selected Industries of the Tehran Stock Exchange
}

\author{
Mahmoud MOEINADDIN ${ }^{1}$ \\ Shahnaz NAYEBZADEH ${ }^{2}$ \\ Masoumeh GHASEMI ${ }^{3}$
}

\author{
${ }^{1}$ Department of Accounting, Yazd Branch, Isla mic Azad University, Yazd, Iran \\ Safaieeh, Shoahadegomnam Road, Zip code: 89195/155, Yazd, Iran \\ Tel: (++98)351-8211391; Fax: (++98)351-8214810 \\ ${ }^{1}$ E-mail:mahmoudmoein@qmail.com, ${ }^{3}$ E-mail: Masoomehqhasemy@yahoo.com \\ ${ }^{2}$ Department of Management, Yazd Branch, Isla mic Azad University, Yazd, Iran \\ Safaieeh, Shoahadegomnam Road, Zip code: 89195/155, Yazd, Iran \\ Tel: (++98)351-8211391; Fax: (++98)351-8214810 \\ 2E-mail: snayebzadeh@gmail.com
}

\begin{abstract}
The main objective of this study is to examine the relationship between product market competition and capital structure of the selected industries on the Tehran Stock Exchange. Considering Tobin's $Q$ and Herfindahl-Hirschman index as the independent variable and the debt ratio as the dependent variable, the research model is developed. This is an applied study classified as the descriptivecorrelation study. The sample covers 89 listed firms on the Tehran Stock Exchange during a period over 2007 to 2011. The collected data is analyzed by using multivariate regression executed in EVIEWS software. The findings reveal that there is a significant association between the capital structures of the selected industry and the product market competition. Additionally, applying Tobin's $Q$ and Herfindahl-Hirschman index as the indexes to measure the competitiveness in the product market does not document the significant relationship between product market competition and capital structure. The other findings, however, confirm the nonlinear relationship between Tobin's $Q$ and capital structure.
\end{abstract}

Key words Capital Structure, Market Structure, Product market competition, Tobin's Q, Herfindahl-Hirschman Index

DOI : 10.6007/IJARAFMS/v3-i3/132

URL: http://dx.doi.org/10.6007/IJARAFMS/v3-i3/132

\section{Introduction}

The business entities today are working in highly growing and competitive environment. These entities have to compete with a variety of factors at national and intemational level to remain in this situation. Therefore, they are needed to make new investments by which they could guarantee their stability; these investments require huge financial resources. However, the financial resources and their application should be highly determined to contribute the business earn profits. This is a definite task of the financial manager who specifies the finance resources and illustrates how to allocate them. There are widespread perspectives concerning the relationship between capital market and product market which imply that the director of a corporation should take into account the product market competition in making finance decisions. Financial and industrial economists have increasingly found the association between the product market competition and financial decisions.

In the oligopoly structure of the product market and in the desirable profitable position, the companies try to remove the monopoly and increase their profitability by implementing product maximization strategy and increase their debts (Brander and Lewis, 1986). According to another theory, the unsatisfactory economical positions cause the businesses to cease their production and decrease their profitability (Pandey, 
2004). On the other hand, the improper capital structure increases the likelihood of financial turmoil and bankruptcy. Once the businesses are not capable of repaying their debts, they are exposed to financial turmoil costs. In this situation, increasing debts by this business leads the time of bankruptcy get doser. Consequently, the corporations guarantee their survival by decreasing their debts (Scott, 1976).

From the point of view of the financial manager, capital structure is one of the most significant topics which have been much debated for about two prior decades. The credit degree of the corporations largely depends on their capital structure. The capital structure of the corporations is an initial sign of the financial pressure and should be seriously taken into account for determining the factors impacting the efficiency of the finance decisions. The trade-off theory of product market and manufacturing elements is one of the theories related to the capital structure. Based on this theory, there is a direct relationship between the capital structure and product market strategy and manufacturing elements. The studies represent that those companies producing highly elastic productions use more debt in their capital structure. In turn, the single high quality production companies use less debt in their capital structure.

The finance decisions of the companies might change in terms of the product market and its situations. Finance and capital structure are the two important fields having essential impact on the competitive ability of the companies. On the other hand, competitive ability specifies the business excellence. They compete to increase their return on investment, stabilize their place in the market or get their competitors out of the market. As a result, this study examines the relationship between product market competition and capital structure.

\section{Literature Review}

\subsection{Theoretical Bases of Capital Structure}

According to the modern financial theories, a financial manager of a business holds the responsibility to make investment, finance and dividend decisions. Making finance decisions is the major task of the companies in determining the best financial compound or capital structure. There are different definitions made for the capital structure; however, each definition specifies an aspect of finance as the capital structure. Cooper (1983) believes that capital structure is the ratio of older securities to the total investments. Belkoui (1999) introduces capital structure as the total claim of the company over its assets. He also argues that capital structure includes items such as the public issued securities, private investments, bank debts, commercial debts and so on. These ratios are calculated as the debt to the total assets, owners' equity to total assets and debts to the owners' equity ratio. Hussey defines capital structure as the balance between debts and assets, borrowing mix and assets' nature.

\subsection{Capital Structure Theories}

Capital structure was first introduced by Modigliani and Miller in the 1960s. They asserted that the capital structure should be captured for evaluating and recognizing the companies. In their first article, they explained that once a company is able to change its market value, the investors can carry out those operations to improve the debt position. The profits of the company, however, is minimized when the investors' earnings is zero (Miller, 1988).

The modern theory of capital structure mentioned in the well-known paper of Modigliani and Miller in 1985 is based on the value independence of the company from the capital structure. Assuming the lack of taxable income, they argued that the value of a leveraged company is the same as an unleveraged one. Considering the taxable income, Modigliani and Miller (1963) suggested that the companies use debts completely to maximize their value and this helps them possess more tax benefits. While borrowing provides tax benefits for the company, the firm value is a direct function of the borrowing level or financial leverage. By regarding the deficiencies of capital market such as bankruptcy and agency costs, they get to a desirable capital structure intended to finance through debts (Ross et al, 2002). 


\subsection{Theoretical Bases of Product market competition}

\subsubsection{Market Structure}

Market is constituted of the whole buyers and sellers of a specific product. Market structure is defined as the competitive position in which the buyers and sellers of the products operate and it is an indicator of the organizational characteristics of the market. Market structure is composed of those organizational characteristics of the market by which their identification might specify the pricing and market competition. There are typically four different types of market structure including perfect competition and monopoly as the two limit structures of the market; and oligopoly and monopolistic competition as the average limits.

\subsubsection{Measuring Market Capital and Competition}

Market concentration involves the extent to which the companies participate in the market. In other words, market concentration indicates the level at which the market productions belong to a number of a large company. Concentration index should provide information about the number of the companies and the market distribution among them. In fact, it provides a comprehensive image of the market structure. Jacobson et al (1996) defines concentration as the degree of competition or complete control over the market. Concentration might be also computed in a general format or at the economical or industrial level. Higher competition represents the imperfect structure of competition and low concentration of strongly competitive structure (Bello, 2009).

The most important indexes of concentration indude: firm concentration ratio, Herfindahl -Hirschman index, reverse number of the entities, Entropy index and variance of log of firms' size. Among these indexes, Herfindahl - Hirschman index is a stronger index and is more common in calculating concentration level. Rathinasamy et al (2000) argue that the market power might be measured by Lerner index, HerfindahlHirschman or Tobin's Q. This study, however, applies Tobin's Q and Herfindahl - Hirschman.

\section{Tobin's Q Index}

Tobin's $Q$ is a common performance evaluation measure introduced in 1970 s by Prof. James Tobin who tried to predict the future investments involved in macro economics analyses. If Tobin's $Q$ is greater than 1.0, then the market value is greater than the value of the company's assets. However, when this ratio is less than one it can be concluded that there is not sufficient return on assets and investments on the assets should be rejected (James Tobin, 1969).

Lindberg and Ross (1981) showed that Tobin's Q is a very strong and complete indicator of market power of the institution. Pandey (2004), Chang and Pruitt (1994) used Tobin's $Q$ as a proxy for the market competition. However, the relationship between Tobin's $Q$ and product market competition is vague. In the perfect competition markets, Tobin's $Q$ ratio for the whole firms is equal to one. It is expected that those firms with the Tobin's $Q$ ratios greater than one have less competitive advantage. That is, the greater of this ratio indicated more concentration and less competition in the industry and vice versa.

\section{Herfindahl - Hirschman Index}

Herfindahl - Hirschman Index measures the concentration level of the industry. This index ranges from 0 to 1 . The greater of this ratio confirms the more concentration and less competitiveness and vice versa. Considering this ratio, it is clear that larger firms possess more significance in constructing this index and measurement of the market concentration. This index is frequently used in creating competitive situation.

\subsection{Bases of the Relationship between Capital Structure and Competitiveness in Product Market}

Harris and Raviv (1991) introduced four determinants of capital structure and suggested that researching capital structure is concentrated on four factors. Based on these factors, product market competition is one of the factors of capital structures. The first and second factors represent the agency view and information asymmetry view in relation to capital structure, respectively. The third factor deals with impacting the results of the competitions for executing control over firms and documents the relationships between capital structure and competitiveness for the directors of the firm. The fourth one concerns the nature of the productions or competitiveness in the product market. This factor shows the association between capital structure and product market strategy and production factor. It is not, however, extended 
yet. The studies demonstrate that in monopolistic competition, much more debt is utilized. Those firms manufacturing highly elastic demand productions use more debt in their capital structure; while the opposite holds for those companies manufacturing single products with high quality.

\subsubsection{Stakeholder Theory of Capital Structure}

There are two frameworks which link the capital structure and competition in the product market. The first group is the stakeholder theory of capital structure. This theory discusses that the debt is not only used by the bondholders, but also by the non-financial shareholders such as customers, employees and suppliers.

Titman (1984) argues that the debt is also influenced by the non-financial shareholders. Liquidation of those firms with durable and monopolistic productions might impose costs such as lack of attainment to the services and products of the firm for the consumers or suppliers of the production elements. Consequently, the need to establish long-term business relationships with the customers or suppliers leads to less utilization of leverage. Maksimovic and Titman (1991) showed that once a firm is known as a famous manufacturer, it is capable of producing high quality productions with excessive costs merely to survive its reputation in the market. Confronted with bankruptcy, the firms become less interested in manufacturing high quality products. This is because of the debt pressure which leads those firms utilize less debts in their capital structure.

\subsubsection{Capital Structure and Competitive Strategy of the Firms}

The second group utilizes the industrial organizes and studies of strategic management for some elements of capital structure. The capital structure should be observable and the company does not allow for the change in the structure before making investment decisions. Consequently, the competitors observe the capital structure and prevent its impact on the subsequent product decisions and investments.

\subsection{Factors Impacting Capital Structure}

The present study considers some observable characteristics of the sample firms as the control variables to control the possible factors affecting capital structure. In this section, short descriptions related to the concept and types of the impacts are provided.

Industry Type

Those firms operating in one industry own similar business risks because they produce the same productions and possess material and labor the same as the other firms of an industry. Classification of a firm in an industry specifies the business risk associated with that industry. Therefore, financial leverage of each industry is different from the other industries. Risk of the assets, their classification and the need to foreign funds are different for various industries. That is why the industrial classification of the firms is regarded as a significant element in leverage determination (Myers, 1984; Harris and Raviv, 1991).

Furthermore, some characteristics such as concentration degree or technological changes influence the debt ratio (Viviani, 2008). On the other hand, some of the market characteristics such as the number and the relative power of the buyers and sellers, level and forms of competition, distinction level of the production and facility in entering or leaving the market are not similar in all industries. Consequently, industry type might affect the market structure (Bello, 2009).

\section{Return on Assets (Profitability)}

Profitable firms are able to accumulate more profits in comparison with the non-profitable ones and they will use retained earnings for making new investments and will then have less borrowing. In other words, profitability and financial leverage are negatively associated (Myers, 1984).

The findings reported by Titman and Wessels (1988), Rajan and Zingales (1995), Bott et al (2000) confirm those results documented by Myers. However, Jensen (1986) and Long and Malitz (1985) assert the positive relationship between financial leverage and profitability in the efficient market situation; while they argue that the inefficient market indicates the negative association between profitability and leverage (Hang and Song, 2005). 


\section{Firm Size}

The firms with great volume of sales or assets are classified as big firms. From the point of view of the creditors, a big firm has much credit for receiving debts and has no problem in repaying the amount of debts. Marsh (1982) found that big firms frequently select long-term debts. These firms have more bargaining power against the creditors because the cost of issuing debts and stocks are inversely related to the firm size. Fama and Jensen (1983) argue that the bigger firms are more likely to provide information for the creditors. Additionally, the empirical studies of Marsh (1982), Bott et al (2001) confirm the positive association of the leverage and firm size. However, the studies of Rajan and Zingales (1995) and Waled (1993) indicate that the big German firms are less likely to use debts (Hang and Song, 2005).

\section{Collateral Value of Assets}

Most of the capital structure theories argue that the type of the assets owned by the firm impact the selection of capital structure. Myers and Majlouf (1984) believe that the managers of the companies are more informed than the outsiders; therefore debts repayment and collaterals by using the assets of the firm prevent the waste of the debts and credits. For this reason, the firms receive more credit by utilizing assets as the collaterals. They also are able to make the best use of the future investment opportunities.

\section{Growth Opportunity}

Once the total level of operations of a business major is growing, the firms of that industry try to extend a variety of operations and need more financial resources. Taking efforts to attain the long-term financial resources stimulate the firms to move toward the financial markets. Some scholars such as Fama and French (1992) believed that the financial pressure seems to be greater for those firms confronted with more growth opportunities. As a result, debt ratio and growth opportunities are negatively associated.

\section{Uniqueness of the Assets}

Titman and Wessels (1988) suggest that uniqueness of the assets makes changing the skills or productions by the employees or suppliers more difficult. This would increase the liquidation cost of the firm to a large extent and leads the firms to use less debts. That is, it is expected that uniqueness of the assets negatively deals with the debt ratio.

\section{Production Capacity of Internal Resources}

Consistent with the stable balance theory, Jensen (1986) argues that higher capacities of creating free cash flows might be positively associated with the debt ratio because the more ability of creating internal resources frequently causes the firms to use higher leverage for attaining tax benefits.

\section{Current Ratio}

Current nature of the assets might increase their solvency so that they are more likely to use higher leverage. Anyway, current ratio is not possibly influencing on the debt level in the firms with much long-term debts.

\section{Literature Review}

Brander and Lewis (1986) found that there is a significant relationship between the product market and financial decisions of the firms. Assuming the oligopoly market in which the financial and manufacturing decisions are consecutively made, they showed that the limited liability leads the obligor firm to select a more aggressive policy of production to receive more return. This process develops a new index for the ratio of debt to capital because the firms are more likely to affect the production market through their financial structures. Examining the association of capital structure and competition ability, Smith and Anderson (2008) found that by increasing the sales ratio of an industry to another one, the long-term debts will increase. It might be interpreted that sales growth causes firms to select aggressive competitive strategies and more leverage for continuous competitiveness.

Pandey (2004) also documented the significant relationship between the capital structure and market power on one hand and capital structure and profitability, on the other hand. In investigating the determinants of the capital structure of the firms, Karadeniz et al (2009) found that tax rate, tangible fixed assets and profitability are negatively associated with the capital structure; while the free cash flows, sales growth and firm size are not related to the capital structure. The findings of Lyandres (2003) imply that a level 
of competition reflection among the firms positively impacts their leverage level independent of the competition type.

Philip Valta (2009) conducted an empirical study to find how the competition of the product market affects the finance costs. They found that intensifying the competition in the product market significantly increases the costs of the bank loans. In another study by Schargrodsky (2002), it was represented that oligopoly market has a greater ratio of debts than the monopoly markets by capturing other factors impacting the leverage. Estiti and Rodriques (2006) investigated the association of between capital structure, stakeholders' theory and market structure. They represented that higher leverage leads to more concentration of the industry. However, highly concentrated firms tend to use more debts.

In another study by David et al (2012), the relationship between capital structure and product market in New Zealand has been examined and their findings implied that using leverage by the publicly held corporations leads to relative increase in sales growth and relative decrease in ROA. Sumitra and Malabika (2011) investigated the impact of product market competition on the capital structure by considering the effects of market structure, behavior and performance on the two ratios of short-term and long-term debts. They suggested that structure and behavior are negatively related to short-term debts; while the performance has a continuous negative effect on the ratios of short-term and long-term debts.

\section{Methodology}

This study seeks to examine the association of competition of the product market and capital structure of the listed firms on the Tehran Stock Exchange. We also suggest firms to perceive the relationship between these two items and take some cases into account such as market and competitors' situation for making finance decisions. Therefore, this is an applied study examining the correlation between the variables. Five main hypotheses and two subsidiary ones have been designed and tested:

H1: Tehran listed firms have different capital structures in terms of different industries.

H2: Competition in the product market of different industries in Tehran Stock Exchange is different.

H3: There is a significant relationship between the capital structure and competition of product market.

H3a: Using Tobin's $Q$, there is a significant relationship between product market competition and capital structure.

H3b: Using Herfidahl-Hirschman index, there is a significant relationship between capital market competition and capital structure.

H4: There is a nonlinear relationship between product market competition and capital structure.

The population of this study is comprised of five selected industries including food, tile and ceramic, plastic and rubber, Iran Khodro and spares and textures listed on the Tehran Stock Exchange from the beginning of 2007 to 2011 . Systematic filtering has been used to select the sample of this study. In doing so, the samples are selected by capturing the five following criteria:

1. The firms are listed on the Tehran Stock Exchange before 2007.

2. The end of the fiscal years is consistent with the calendar year.

3. The firms are continuously listed on the Tehran Stock Exchange.

4. The firms have not changed their fiscal years.

5. The information of these firms is available.

Considering the above mentioned measures, 89 firms are selected as the sample. The needed data is collected by different methods. Using prior literature review, archive studies and research background, the data related to the research variables is collected and analyzed by SPSS and EXCEL software. Finally, 445 observations are obtained.

\section{Measuring Variables and Extension of Research Models}

\subsection{Definition of the Variables}

The dependent variable of this study is the capital structure or financial leverage calculated by dividing total debts to total assets. Tobin's $Q$ is used to measure the competition in the product market. In addition, $\mathrm{HHI}$ index is also applied as the competition index to test the third hypothesis more accurately. 


$$
Q=\frac{\text { Market value of owner's equity }+ \text { book value of the debts }}{\text { Book value of the assets }}
$$

$\mathrm{HHI}$ measures the concentration level of the industry. This index is calculated by the square of market share of the whole firms operating in the industry. Market share of the firm $\left(s_{i}\right)$ is calculated by the ratio of productions of the firm to the total productions of the market. This index can be measured as follows:

$$
\begin{aligned}
& H H I=s_{i}^{2} \\
& s_{i}=\frac{x_{j}}{\sum_{i=1}^{n} x_{j}}
\end{aligned}
$$

In the above equation, $x_{j}$ is the sales of firm $j$ and $i$ is the industry type. Some of the observable characteristics of the sample firms are considered as the control variables to execute control over other possible factors influencing capital structure. The definitions of the variables are provided in the literature review section of this study. In this section the variables are functionalized.

1. Return on Assets (ROA)

$$
\text { ROA }=\frac{\text { Net income }}{\text { Total assets }}
$$

\section{Firm Size (SIZE)}

This variable is computed by the natural log of total assets.

\section{Collateral Value of Assets (CVA)}

Tangible assets can be used as the collateral to pay the debts. Therefore, the collateral value of the assets is either positively or negatively related to the debts. This variable is computed by using the two following indexes:

$$
\begin{aligned}
& \text { CVA1 }=\frac{\text { Inventories }+ \text { Fixed Assets }}{\text { Total assets }} \\
& \text { CVA2 }=\frac{\text { Total Assets-Intangible Assets }}{\text { Total assets }}
\end{aligned}
$$

4. Growth Rate (GR)

The firms which confront with higher growth opportunities are more expected to be more flexible and earn more future profit in theirfuture investments. This variable is calculated by the two following indexes:

$$
\begin{aligned}
& \mathrm{GR}-\mathrm{TA}=\frac{\text { Total Assets in year }(\mathrm{t})-\text { Total assetsin year }(\mathrm{t}-1)}{\text { Total assetsin year }(\mathrm{t}-1)} \\
& \mathrm{GR}-\mathrm{OI}=\frac{\text { Total salesin year }(\mathrm{t})-\text { Total salesin year }(\mathrm{t}-1)}{\text { Total salesin year }(\mathrm{t}-1)}
\end{aligned}
$$

5. Uniqueness of the Assets (UNIQ)

$$
\mathrm{UNIQ}=\frac{\text { Operating Expense }}{\text { Sales }}
$$

\section{Capability of Generating Internal Resource}

$$
\text { CGTR }=\frac{\text { Net Operating Cash Flows }}{\text { Total Assets }}
$$

7. Current Ratio (CR)

$\mathrm{CR}=\frac{\text { Current Assets }}{\text { Current Liabilities }}$ 


\subsection{Research Models}

Three regression models are applied to examine the impact of product market competition on the capital structure. These models examined capital structure in a static form. The model components are described below.

Model 1: The relationship between product market competition and static capital market

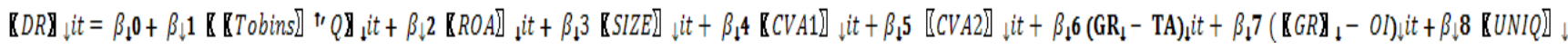

Where:

$i$ =The examined firm; $t$ = The period; DR it= Debt ratio; Tobins 'Qit = Tobin's $Q$ ratio;

ROA it = Return on Assets; SIZE it = Firm Size; CVA1 it = Collateral value of the assets;

CVA2 it = Collateral value of the assets; $($ GR_TA $)$ it = Growth rate; $($ GR_OI) it = Sales growth rate;

UNIQ it = Uniqueness of the assets; CGIR it = Capability of generating internal resources;

$\mathrm{CR}$ it $=$ Current ratio; $\varepsilon_{i t}=$ Error of regression equation .

Model 2: Herfindahl-Hirschman Index

$D R_{i t}=\beta_{0}+\beta_{1} H H I_{i t}+\beta_{2} R O A_{i t}+\beta_{3} S I Z E_{i t}+\beta_{4} C V A 1_{i t}+\beta_{5} C V A 2_{i t}+\beta_{6}\left(G R \_T A\right)_{i t}+\beta_{7}\left(G R_{-} O I\right)_{i t}+\beta_{8} U N I Q_{i t}+\beta_{9} C G I R_{i t}+\beta_{10} C R_{i t}+\varepsilon_{i t}$

\section{Model 3. Examining the non-linear relationship}

For the purpose of investigating the possibility of the nonlinear relationship between product market competition and capital structure, this model is estimated by the dependent and control variables of the prior models with TOBIN ${ }^{2}$ AND QTOBIN ${ }^{3}$ as the independent variable. Tobin's $Q$ is the index of product market competition. To investigate this nonlinear relationship, the following model is estimated:

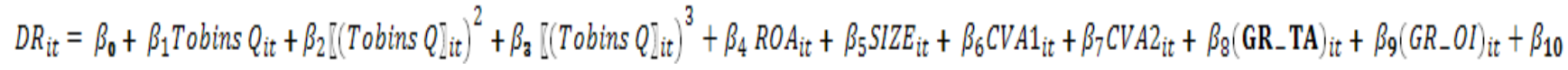

$\mathbb{Z}\left(\text { Tobins } Q Q_{i t}\right)^{2}=$ Tobin's $Q$ ratio squared; $\mathbb{Z}\left(\text { Tobins } Q Q_{i t}\right)^{a}=$ The third exponentiation of Tobin's Q

\section{Analyzing the Empirical Findings}

In this section, ANOVA is used to test the first and second hypotheses concerning with the significant difference between capital structure and competition of product market in the Tehran Stock Exchange. In ANOVA, the sources of the changes are classified into two classes of intra-groups (difference between the societies or groupings of the researcher) and inter-groups (other factors or errors). This test examines the degree to which the dispersions come from the first or the second group. Consistent with the findings, the significance of the statistic is less than the expected error level (5\%) and it confirms that the differences are not largely due to other factors (inter-group).

Table 1. ANOVA results for $\mathrm{H} 1$

\begin{tabular}{|ccccccc|}
\hline & Total Squared & $\begin{array}{c}\text { Degree of } \\
\text { Freedom }\end{array}$ & $\begin{array}{c}\text { Mean of Total } \\
\text { Squared }\end{array}$ & F. Statistics & $\begin{array}{c}\text { Error } \\
\text { Level }\end{array}$ & Hypotheses \\
Intra-group & $66 / 044$ & 4 & $16 / 511$ & $31 / 02$ & $0 / 000$ & HO is rejected \\
Inter-group & $234 / 197$ & 440 & $0 / 532$ & & & and H1 is \\
Total & $300 / 24$ & 444 & & & confirmed \\
\hline
\end{tabular}

Table 2. ANOVA results for $\mathrm{H} 2$

\begin{tabular}{|ccccccc|}
\hline & $\begin{array}{c}\text { Total } \\
\text { Squared }\end{array}$ & $\begin{array}{c}\text { Degree of } \\
\text { Freedom }\end{array}$ & $\begin{array}{c}\text { Mean of Total } \\
\text { Squared }\end{array}$ & $\begin{array}{c}\text { F. } \\
\text { Statistics }\end{array}$ & $\begin{array}{c}\text { Error } \\
\text { Level }\end{array}$ & Hypotheses \\
\cline { 1 - 6 } Intra-group & $112 / 658$ & 4 & $28 / 165$ & $16 / 621$ & $0 / 000$ & Ho is rejected \\
Inter-group & $745 / 571$ & 440 & $1 / 694$ & & & and H2 is \\
cotal & $858 / 229$ & 444 & & & & confirmed \\
\hline
\end{tabular}

As shown in tables 1 and 2, ANOVA results of the hypotheses show that the error level of the Fischer statistic is less than 0.05 . Accordingly, $\mathrm{H} 1$ and $\mathrm{H} 2$ confirm the significant relationships between capital structure and product market competition in different industries at a level less than $5 \%$. 
To test $\mathrm{H} 3$, the independent variable (product market competition) is calculated by using Tobin's $\mathrm{Q}$ and Herfindahl-Hirschman index. Additionally, Limer and Hausman tests are applied to determine the methods to test the subsidiary hypotheses of the third main hypothesis. These findings are represented in tables 3 and 4. According to Limer test, $\mathrm{HO}$ suggests using the pooling normal least squares. In other words, rejecting $\mathrm{HO}$ indicates using of mixed data (random or fixed effects). Findings related to Limer test for each one of the third subsidiary hypothesis are shown in table 3 . As it is clear, $\mathrm{HO}$ of the Limer test is rejected and the mixed data should be therefore applied.

Table 3. Limer test results for $\mathrm{H} 3 \mathrm{a}$

\begin{tabular}{|lccc|}
\hline & Statistic & Error level (prob) & Result \\
\hline H3a & $9 / 85$ & $0 / 000$ & Fixed or random effects \\
\hline H3b & $10 / 86$ & $0 / 000$ & Fixed or random effects \\
\hline
\end{tabular}

According to Hausman test, rejecting HO suggests using fixed effects. Table 4 provided the findings related to the tests of each one of the subsidiary hypothesis. Accordingly, the probability level of this statistic is less than $5 \%$ and it shows that the fixed effect method should be used for estimating the models.

Table 4. Hausman test results for $\mathrm{H} 3 \mathrm{a}$

\begin{tabular}{|cccc|}
\hline & Statistic & Error level (prob) & Result \\
\hline H3a & $279 / 19$ & $0 / 000$ & Fixed effect \\
\hline H3b & $208 / 96$ & $0 / 000$ & Fixed effect \\
\hline
\end{tabular}

Implementing regression model for $\mathrm{H} 3 \mathrm{a}$, the coefficients of the model are estimated and the relationship type is analyzed. According to table 5, Tobin's $Q$ index is directly associated with the capital structure. However, t statistics (1.808238) of the calculated regression coefficient for this variable is not significant. Therefore, this hypothesis is confirmed and it is concluded that the re is a significant relationship between Tobin's $Q$ ratio and capital structure.

Examining the control variables related to the capital structure, $t$ statistics of ROA and the regression coefficient of the regression are significant and confirm the positive association with the capital structure. Based on the t statistics for CVA1 and CVA2, the regression coefficients of these variables are significant and have an inverse relationship with the capital structure. Additionally, $t$ statistics of CR represents that the regression coefficient is significant and the inverse relationship with the capital structure is confirmed.

Table 5. Findings of regression model for $\mathrm{H} 3 \mathrm{a}$

\begin{tabular}{|c|c|c|c|}
\hline variable & $\begin{array}{l}\text { Variable } \\
\text { Coefficient }\end{array}$ & t statistics & Sig. \\
\hline (Constant) & $6.235816^{* * *}$ & 1.898098 & 0.0585 \\
\hline QTOBIN & $0.027429 * * *$ & 1.808238 & 0.0714 \\
\hline ROA & $0.005831^{*}$ & 2.760617 & 0.0061 \\
\hline SIZE & $0.122579 * * *$ & 1.724014 & 0.0856 \\
\hline CVA1 & $-0.901494 *$ & -4.710737 & 0.0000 \\
\hline CVA2 & $-6.0134 * *$ & -2.031521 & 0.0430 \\
\hline GRTA & 0.000580 & 1.117547 & 0.2645 \\
\hline GROI & -0.000414 & -0.520513 & 0.6030 \\
\hline UNIQ & 0.337911 & 1.488635 & 0.1375 \\
\hline CGIR & -0.153495 & -1.342679 & 0.1803 \\
\hline \multirow[t]{3}{*}{$\mathrm{CR}$} & $-0.797378^{*}$ & -30.39443 & 0.0000 \\
\hline & & \multicolumn{2}{|c|}{0.8708 :Durbin- Watson 2.015} \\
\hline & & \multicolumn{2}{|c|}{ : Sig.0.000 } \\
\hline \multicolumn{4}{|c|}{$* P<0.01, * * P<0.05, * * * P<0.10$} \\
\hline
\end{tabular}


Table 6 also reveals the similar findings related to the implementation of the regression model for H3b. As shown in table 6, $\mathrm{HHI}$ index is directly associated with the capital structure. Accordingly, it is conduded that $\mathrm{H} 3 \mathrm{~b}$ is not confirmed and it might not be concluded that $\mathrm{HHI}$ and capital structure are confirmed at $95 \%$ of significance level.

Table 6. Findings of regression model for $\mathrm{H} 3 \mathrm{~b}$

\begin{tabular}{|c|c|c|c|}
\hline Variable & Variable coefficient & t statistics & Sig. \\
\hline (Constant) & $6.877511^{* *}$ & 2.080744 & 0.0382 \\
\hline $\mathrm{HHI}$ & 2.940163 & 1.130193 & 0.2592 \\
\hline ROA & $0.005652 *$ & 2.667219 & 0.0080 \\
\hline SIZE & 0.099821 & 1.402957 & 0.1615 \\
\hline CVA1 & $-0.932981^{*}$ & -4.889160 & 0.0000 \\
\hline CVA2 & $-6.364833^{* *}$ & -2.135982 & 0.0334 \\
\hline GRTA & 0.000541 & 1.035362 & 0.3012 \\
\hline GROI & -0.000375 & -0.469782 & 0.6388 \\
\hline UNIQ & 0.375030 & 1.647064 & 0.1005 \\
\hline CGIR & -0.144692 & -1.263926 & 0.2071 \\
\hline CR & $-0.800592 *$ & -30.36174 & 0.0000 \\
\hline & \multicolumn{3}{|c|}{0.8701 :Durbin-Watson1.9859 } \\
\hline \multicolumn{4}{|c|}{$* P<0.01, * * P<0.05, * * * P<0.10$} \\
\hline
\end{tabular}

The findings related to this hypothesis prove that there is no significant linear relationship between product market competition and capital structure. Consequently, the model was replicated by adding QTOBIN ${ }^{2}$ and QTOBIN ${ }^{3}$ of the independent variable and the results are provided in table 7. As it is shown, QTOBIN, QTOBIN ${ }^{2}$ and QTOBIN ${ }^{3}$ are significantly related to capital structures inversely, directly and inversely, respectively. Therefore, the fourth hypothesis is confirmed and the nonlinear relationship between QTOBIN and capital structure is validated. Table 8 demonstrates the results related to the hypotheses.

Table 7. Findings of regression models for $\mathrm{H} 4$

\begin{tabular}{|cccc|}
\hline Variable & Variable Coefficient & t statistics & Sig. \\
\hline (Constant) & $6.780979^{*}$ & 2.886358 & 0.0041 \\
\hline QTOBIN & $-0.902328^{*}$ & -9.177007 & 0.0000 \\
\hline QTOBIN2 & $0.327518^{*}$ & 14.71317 & 0.0000 \\
\hline QTOBIN3 & $-0.012457^{*}$ & -15.69507 & 0.0000 \\
\hline ROA & -0.000294 & -0.187170 & 0.8516 \\
\hline SIZE & $-0.060379^{*}$ & -4.518181 & 0.0000 \\
\hline CVA1 & $-0.320122^{*}$ & -3.351920 & 0.0009 \\
\hline CVA2 & -3.743302 & -1.609569 & 0.1082 \\
\hline GRTA & $0.001082^{* *}$ & 1.964872 & 0.0501 \\
\hline GROI & -0.000871 & -1.012664 & 0.3118 \\
\hline UNIQ & -0.006809 & -0.111504 & 0.9113 \\
\hline CGIR & $-0.237383^{*}$ & -2.114121 & 0.0351 \\
\hline CR & $-0.673982^{*}$ & -23.42431 & 0.0000 \\
\hline \multicolumn{5}{c}{$\mathbf{A d j .} R^{2}$} & 0.8120 & Durbin-Watson 1.517 \\
\hline & $F$ & 160.126 & $:$ sig. 0.000 \\
\hline
\end{tabular}


Table 8. Summarized results of testing the hypotheses

\begin{tabular}{|c|c|c|c|c|}
\hline Description & Title & $\begin{array}{c}\text { Type of } \\
\text { Relationship }\end{array}$ & Sig. & Result \\
\hline $\mathrm{H} 1$ & $\begin{array}{l}\text { Examining the distinction of capital } \\
\text { structure for different industries }\end{array}$ & - & Sig. & Confirmed \\
\hline $\mathrm{H} 2$ & $\begin{array}{l}\text { Examining the difference of product } \\
\text { market competition in different } \\
\text { industries }\end{array}$ & - & Sig. & Confirmed \\
\hline $\mathrm{H3}$ & $\begin{array}{l}\text { The relationship between product } \\
\text { market competition and capital } \\
\text { structure }\end{array}$ & 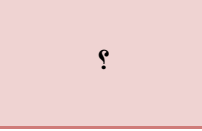 & Sig. & Rejected \\
\hline H3-1 & $\begin{array}{l}\text { The relationship between capital } \\
\text { structure and product market } \\
\text { competition using Tobin's Q }\end{array}$ & Direct & Sig. & Rejected \\
\hline H3-2 & $\begin{array}{l}\text { The relationship between capital } \\
\text { structure and market competition } \\
\text { using } \mathrm{HHI} \text { index }\end{array}$ & Direct & Sig. & Rejected \\
\hline $\mathrm{H} 4$ & $\begin{array}{l}\text { Nonlinear relationship between } \\
\text { capital structure and product market } \\
\text { competition }\end{array}$ & Inverse & Sig. & Confirmed \\
\hline
\end{tabular}

\section{Conclusion and Discussion}

The first main hypothesis concerning the difference between capital structures of the selected firms has been tested. The results suggest that capital structures of the firms in various industries are significantly different. This is consistent with the findings of Scott (1972) and Filing (2003).

Those firms operating in one industry have similar business risks because their productions are the same and their costs of material and labor are also the same as others. Business risk determines the loan and credit level made available for the firms. The business risk is uniquely defined for any of the firms based on the classification in which the firms are categorized.

The results of the second main hypothesis also disclose that the competition of the product market is significantly different for various industries. This finding has been also accepted by Estiti and Rodriquez (2006) and Panedi (2004). Given the significant relationship between the competition in the product market and capital structure of the selected industry, the third main hypothesis is documented and tested. The test results indicate that there is no significant association between product market competition and capital structure of the firms operating in the selected industries of Tehran Stock Exchanges. This result is consistent with the studies of Valta (2009), Panedi (2004), David et al (2012) and Hochaltero et al (2007). Based on the product market and the existing situations, the finance decisions of the firms change. Furthermore, the finance topic and capital structure are essentially considered in relation to product market competition. Capital structure plays a significant role in efficiency and competitive ability of the firms in the market. On the other hand, competitive ability determines the main role in business. The firms begin to compete with each other to increase their return on investment, reinforce their position in the market, dominance over their competitors and become a powerful firm in the industry.

Using the two strong indexes of Tobin's $\mathrm{Q}$ and $\mathrm{HHI}$ to measure the concentration and competition in the product market, the first main hypothesis has been examined in terms of two subsidiary hypotheses. The results of the first subsidiary hypothesis showed that there is no significant association between product market competition and capital structure by using Tobin's Q. Additionally, the findings related to the second subsidiary hypothesis document the insignificant relationship of product market and capital structure by using $\mathrm{HHI}$ index.

The fourth main hypothesis deals with the nonlinear relationship between product market competition and capital structure of the selected industries of the Tehran Stock Exchange. This relationship has been confirmed by the tests mentioned before. The findings are consistent with the results of Panedi (2004). However, QTOBIN and QTOBIN3 are inversely related to the capital structure. It is possible to attribute the 
results to the Tobin's Q nature because it shows the growth opportunity of the firms and the higher Tobin's $Q$ indicates higher growth opportunity. Therefore, the firms are expected to have less reinvestment or fewer dividends and increase their growth opportunity. In doing so, the debts are less used in the capital structure.

\section{Applied suggestions}

According to the direct relationship between the product market competition and capital structure, the firms are suggested to take into account the market situations and competitors in making finance decisions. The borrowing capacity and positive net present value of the projects should be also considered in making such decisions. Confronted with the different competitive situations, the firms are suggested to design intelligent finance strategies and this is according to the nonlinear relationship between product market competition and capital structure confirmed in this study. Designing such strategies contributes firms to influence on the product market and reinforce their position in the market and finally increase their market share.

Based on the direct association of product market and capital structure indicated in this study, the investors are suggested to stimulate firms to disclose more information about the market share of their productions. This is the information which might affect the expected earnings of the investors and the probability of bankruptcy. The investors are also proposed not to rely merely on the profitability of the firms; it is better to pay attention to some items such as the position of the firm in the industry, the current position of the firm in the product market, compound of the capital structure and trend of creating debts for the firms and competitors.

\section{References}

1. Bello, H. M., Sepiriti M., \& Letete E. M. (2009)," Competition, Market Structure and Market Power in the Insurance Industry in Lesotho", IUP Journal of Financial Economics 7.( 1) 7-21.

2. Brander, J. A. and T.R. , Lewis (1986), " oligopoly and financial structure: the limited liability effect ", American Economics Review, vol. 76, pp 956- 970.

3. Chung K.H and S.W. Pruitt (1994), " A simple approximation of Tobin' s q", Financial measurement, 23(3), 70-74.

4. David, J.S and Jianguo, C. and Hamish D.A. (2012), "The Relationship between capital structure and Product Markets: Evidence from New Zealand", Review of Quantitative Finance and Accounting, Vol 38,No. 1.

5. Harris, M. and Raviv, A. (1991)," The theory of capital structure ", Journal of Finance,Vol. 46, pp. 297-355.

6. Huang, G. and F. M. Song (2005), "The Determinants of Capital Structure: Evidence from China", China Economic Review , Vol. 17, No 1, pp. 14-36.

7. Istaitieh, A. and Rodriguez, J. M. (2006), " Factor-product markets and firm's capital Structure: A literature review", Review of Financial Economics,Vol. 15, pp. 49-75.

8. Jensen, M. C. (1986), " Agency costs of free cash flows, corporate finance and takeovers ", The American Economic Review, 76(3), 323-329.

9. Kovenock, D. and Phillips, G. (1995), "Capital structure and product-market behavior: An examination of plant exit and investment decisions" Review of Financial Studies, 10 (3), 767-803.

10. Lindeberg, E.B. and Ross, S.A. ( 1981) ," Tobin's q Ration and Industrial organization ", Journal of Business ,54(1), 1-32.

11. Lyandres, E. (2003), " Capital structure and interaction among firms in output markets - Theory and evidence.", Working Paper No . FR 03-13. University of Rochester . New York.

12. Maksimovic, V. and Titman, S. (1991), "Financial policy and reputation for product quality", Review of Financial Studies, 4,pp 175-200.

13. Myers, S. C. (1984), " The capital structure puzzle", Journal of Finance, 39(3), 575-592.

14. Miller, M. (1988). "Debt and Taxes", Journal of Finance, 2,261-275

15. Modigliani, F., Miller, M.H.,( 1958)," The cost of capital, corporate finance and the theory of investment", Am. Econ. Rev. 48, 261-275.

16. Modigliani, F. and Miller, M. (1963), "Corporate income taxes and the cost of capital: a correction", American Economic Review, Vol. 53, June, pp. 443-53. 
17. Myers, S. C. and Majluf, N. S. (1984), " Corporate financing and investment decisions when firms have information that investors do not have" Journal of Financial Economics, 13 (2), 187-221.

18. Pandey, I. M. (2004)," capital structure, profitability and market structure : Evidence from Malaysia", Asia pacific Journal of Economics and business, vol. PP.78-91

19. Philip V. (2009), " Product Market Competition and Financing Costs".

20. Rajan, R. G. and Zingales, L. (1995), "What do we know about capital structure? Some evidence from international data", Journal of Finance, Vol 50, pp. 1421-1460.

21. Rathinasamy, R. S. and Krishnaswamy, C. R. and Mantripragada, K. G. (2000), "Capital structure and product market interaction: An international perspective", Global Business and Finance Review, 5(2), 51-63.

22. Scott, J. H. (1976), "A Theory of optimal capital structure", Bell Journal of Economics, Vol. 7, pp. 3354.

23. Sumitra, N. and Malabika, R. (2011), " Product Market Competition and Capital Structure of firms: The Indian Evidence", Journal of Quantitative Economics, Vol 9, No. 2, pp 140-153

24. Titman, S. (1984)," The effect of capital structure on a firm's liquidation decision", Joumal of Financial Economics, 13(1), 137-151.

25. Titman, S. and Wessels, R. (1988), " The determinants of capital structure choice", Journal of Finance, 43(1), 1-19.

26. Tobin , J.(1969), "A general equilibrium approach to monitory theory" , Journal of Money , Credit and Banking,1(1), 15-29. 